\title{
Analysis of Gonadotropin Releasing Hormone (GnRH), Leutinizing Hormone (LHb) and Follicle Stimulating Hormone (FSHb) Genes in Indian Spiny Loach (Lepidocephalus thermalis)
}

\author{
R. Hamsavalli ${ }^{1}$, J. Jaculine Pereira ${ }^{1}$, K. Karal Marx ${ }^{3}$ and R. Jeya Shakila ${ }^{2}$ \\ ${ }^{1}$ Department of Fisheries Biotechnology, ${ }^{2}$ Department of Fish Quality Assurance and \\ Management, Fisheries College and Research Institute, Thoothukudi, India \\ ${ }^{3}$ Institute of post graduate study, Tamil Nadu Dr. J. Jayalalithaa Fisheries University, OMR \\ campus, Chennai, India \\ *Corresponding author
}

\begin{abstract}
A B S T R A C T
Keywords

Lepidocephalusther malis,

Gonadotropin releasing hormone, Follicle stimulating hormone and leutinizing hormone

Article Info

Accepted:

10 March 2019

Available Online: 10 April 2019

Lepidocephalus thermalis forms a potential candidate species for aquaculture, being a native species it also has high market demand with easy domestication procedure. RNA was extracted from the ovarian tissues of Lepidocephalus thermalis by following the TRIZOL reagent method and cDNA was synthesized. The purity of RNA, cDNA and PCR products were checked. The PCR reactions were carried out with gene specific primers of gonadotropin releasing hormone II, gonadotropin releasing hormone III, leutinizing hormone and follicle stimulating hormone genes and the PCR products size of the four genes were 270-bp for gonadotropin releasing hormone II, 250-bp for gonadotropin releasing hormone III, 290-bp for leutinizing hormone and 260-bp for follicle stimulating hormone. The results from present study will serve as a primary data for further research and development in the reproductive genomic aspects of Indian spiny loach (Lepidocephalus thermalis).

\section{Introduction}

India recites more than $10 \%$ of global fish biodiversity and it also ranks second in the world in total fish production. The capture fisheries were considered as the major contributor of marine sector whereas in inland fisheries, aquaculture constitutes nearly $77 \%$ of total production. India has a rich natural heritage and nurtures a unique biodiversity

placing it among the 12 most biodiverse countries. Out of 31,100 extant fish species 2438 are known from Indian Sub- Continent (Froese and Pauly, 2009). The index of biodiversity utilized for aquaculture in India was of the order of 0.13 ( $85 \%$ from Indian major carps; $\sim 5 \%$ air-breathing fishes; $\sim 10 \%$ rest all species together). Hence, more species need to be brought into culture practice, for the sustainability of aquaculture (Ayyappan $e t$
\end{abstract}


al., 2010). On that note Lepidocephalus thermalis forms a potential candidate species for aquaculture, being a native species it also has high market demand with easy domestication procedure. Although loaches have an ornamental value and native or endemic status in India, very few studies have been carried out so far on their reproductive biology.

Gonadotropin-releasing hormone (GnRH) was a neurodecapeptide, which plays an essential role in regulation of gonad development and final sexual maturation in vertebrate (Gharaei et al., 2011). The secretion of luteinizing hormone (LH), follicle-stimulating hormone (FSH) and other GnRH-associated peptide (GAP) were stimulated by GnRH, which was synthesized in the hypothalamus and in pituitary glands (Yaron, 1995). In teleost fishes, the presence of either two or three forms of $\mathrm{GnRH}$ has been well documented (Kah et al., 2007). The gonadotropin (GTH) includes follicle stimulating hormone (FSH) and luteinizing hormone (LH), which plays significant role in the regulation of fish reproduction. Both FSH and LH are glycoproteins synthesized in the pituitary, consisting in a common $\alpha$ subunit $(\mathrm{GP} \alpha)$ and a hormone specific $\beta$ subunit (FSH $\beta$ and LH $\beta$ ), which provides biological specificity (Yoshiura et al.,1999). The role of FSH predominates during early gonadal recrudescence, including vitellogenesis and spermatogenesis, while function of $\mathrm{LH}$ was more related to final gonadal maturation, ovulation and spermiation.

The genomics of gonadotropin releasing hormone $(\mathrm{GnRH})$, leutinizing hormone (LH), follicle stimulating hormone (FSH) genes will be useful for getting in depth knowledge about the genetic makeup of the species and also helps to understand the reproductive biology of Indian Spiny Loach (Lepidocephalus thermalis). By processing this genomic information we would be able to develop a scientific breeding protocol for Lepidocephalus thermalis in the future. This will pave the way to produce the alternative species for freshwater fish farming community.

\section{Materials and Methods}

The loaches for the experiments were collected from Chola fish farm, Vaduvoor, Thiruvarur District of Tamil Nadu. Stocking density was 40 fishes per 1000 liter tank and sufficient aeration was provided. The bottom of the tanks was filled with sand and small gravels to provide suitable substratum to the fishes. The water temperature was recorded as $26 \pm 0.5^{\circ} \mathrm{C}$ and the $\mathrm{pH}$ 8.3. The fishes were feed twice with pellet feed ad libitum. They were also fed with artemia biomass once in a week. Water exchange was done once in a fortnight. Water was also sprayed at the surface of the tank for 10-15 min at a time for twice or thrice a day to mimic natural monsoon condition, to induce maturity of the fishes.

\section{RNA extraction and preparation of cDNA}

Total RNA was extracted from ovarian tissues of Lepidocephalus thermalis using Trizol ${ }^{\mathrm{TM}}$ reagent (Favourgen Biotech Corp., Taiwan). And $c D N A$ was synthesized from total RNA $(5 \mu \mathrm{g})$ using Revertaid Reverse Transcriptase Enzyme (Thermo Fisher Scientific India Pvt. Ltd., Mumbai) as per the manufacturer's instructions.

\section{PCR amplification of cDNA of GnRH II, GnRH III, LHb and FSHb genes}

PCR (Eppendorf AG, Germany) was performed to amplify the desired cDNA fragments from the template. PCR amplification was performed in a total volume of $25 \mu \mathrm{l}$ volume including $21 \mu \mathrm{l}$ of Taq $2 \mathrm{X}$ 
PCR master mix red (1.5 U Taq DNA polymerase) with $1.5 \mathrm{mM} \mathrm{MgCl}_{2}$ (Ampliqon, Denmark), $1 \mu \mathrm{l}$ forward primer, $1 \mu \mathrm{l}$ of reverse primer and $2 \mu \mathrm{l}$ of template cDNA. The PCR amplification conditions (Table 2) included an initial denaturation at $94^{\circ} \mathrm{C}$ for 2 min, followed by 35 cycles of $94^{\circ} \mathrm{C}$ for $30 \mathrm{~s}$, $52^{\circ} \mathrm{C}\left(\mathrm{GnRH}\right.$ II and GnRH III) $/ 51^{\circ} \mathrm{C}(\mathrm{FSHb})$ $/ 53^{\circ} \mathrm{C}(\mathrm{LHb})$ for $40 \mathrm{~s}, 72^{\circ} \mathrm{C}$ for 1 min with a final extension of $72^{\circ} \mathrm{C}$ for $10 \mathrm{~min}$ followed by $4^{\circ} \mathrm{C}$ forever. Primer used for amplifying GnRH II, GnRH III, LHb and FSHb genes were in table 1 . The PCR product sizes were determined by $2 \%$ agarose gel electrophoresis run along with DNA marker i.e., 100bp DNA ladder.

\section{Results and Discussion}

The total RNA was extracted from the ovarian tissues of loach and from the RNA (Fig. 1) isolates cDNAs of GnRH II, GnRH III, FSHb, $\mathrm{LHb}$ were synthesized using the specific reverse primers. The RNA was electrophoresed through $1 \%$ agarose gel containing ethidium bromide (Fig. 1). By using the synthesized cDNA of GnRH II, GnRH III, LHb and FSHb amplification was carried out by PCR to amplify the GnRH II, $\mathrm{GnRH}$ III, LHb and FSHb genes. PCR product sizes were 270 for GnRH II, 250 for GnRH III, 290 LHb and 260 for FSHb (Fig. 2 and 3 ).

Gonadotropin-releasing hormone $(\mathrm{GnRH})$ is well known for its role in moderating gonadotropin release from the pituitary. $\mathrm{GnRH}$ is a member of family of neuropeptides that play a key role in the development and maintenance of reproductive function in vertebrates. The midbrain neuron population in fish is believed to be exclusively GnRH-II-producing neurons and these cells are suggested to play a role in reproductive behavior (Sherwood and Adams, 2005). The PCR amplified product size of
GnRH II gene examined in this study was 270 bp from ovarian cells of Lepidocephalus thermalis for the primers forward 5'ATGGTGCTGGTCTGCAGGTG-3' and reverse 5'-GTAGGAACTGCTGCAAATG GGT-3' whereas in hard-lipped barb (Osteochilus hasselti) Prayogo et al., (2011) amplified a product of $253 \mathrm{bp}$ from brain cells using the primers forward 5'CCTAAGATGGTGCACATCTGCAGGCT3' and reverse 5'-GGGCTCGAGTCTT TTGGAAATCCCGT-3' and in catla (Catlacatla) Rather et al., (2015) amplified a product of $202 \mathrm{bp}$ from brain cells using forward 5'-ATGGATCCGTGAGATTGCA CCAA-3' and reverse 5'-GTTTCTTCCCTG GGGTCTCAGGTAGC-3'. The brain cells were not used in this study because the size of the brain of L.thermalis is too small (insufficient in quantity) to carry out the genomic analysis, therefore the analysis was conducted on the ovarian tissue only.

GnRH III gene is expressed mainly in the olfactory system. GnRHIII constitutes the main hypophysiotrophic factor governing the release of gonadotropins from the pituitary gonadotropes and these neurons innervate the pituitary (Kah et al., 1986). The highest content of pituitary GnRH is the form that is found in the preoptic neurons (Carolsfeld et al., 2000; Collins et al., 2001; Amano et al., 2002). The amplified PCR product of GnRH III in the present study was $250 \mathrm{bp}$ from ovarian cells of Lepidocephalus thermalis using primers forward 5'CACAGCAGTTTTAGCATGGAGTG-3' and reverse 5'- ACACTCTTCCCC GTC TGTCGG-3'. Prayogo et al., (2011) reported that in hard-lipped barb (Osteochilus hasselti), a product of $285 \mathrm{bp}$ for GnRH-III from brain cells using the primers forward 5'GGACCTAAG AGCATGGAGTGGAAAG GAAG-3' and reverse 5'- GGGCTCGAG CACTCTTCCTCGTCTGTT GG-3'. 
Gonadotropins (GTHs), follicle stimulating hormone (FSH) and luteinizing hormone $(\mathrm{LH})$, are critical hormones in the regulation of reproduction in vertebrates, including fish (Yaron et al., 2003). FSH is involved in the initiation of gametogenesis and regulation of gonadal growth, whereas LH mainly regulates gonadal maturation, spermiation and ovulation. FSH and LH are complex heterodimeric glycoproteins, consisting of a common $\alpha$ subunit and a hormone-specific $\beta$ subunit, encoded by different genes (Pierce and Parson, 1981; Yoshiura et al., 1999). Both subunits bind non-covalently into the gonadotropic cell, to form the biologically active dimeric hormone (Pierce, 1988). The first teleost $\mathrm{LHb}$ subunit gene to be isolated and sequenced was that of the Chinook salmon, Onchorhynchus tshawytscha (csGtHIIb or csLHb) by Xiong and Hew (1991). The product size of LHb reported by Rather et al.,(2016) was 629 bp in catla (Catlacatla) from brain cells using forward 5'-GTCCTACTAGCTGTTGCTCAAAGC TC-3' and reverse 5'-CATAGTGCACAGG CTGCAGTCGC-3' primers. In the present study, the PCR product size of $\mathrm{LHb}$ was 290 bp from ovarian cells of Lepidocephalus thermalis using the primers forward 5'CAAGAGCCCATTTTCCAC-3' and reverse 5'-AGGCTGCAGTCGACAGCT-3'. The $\mathrm{LHb}$ product size in Zebra fish was $958 \mathrm{bp}$ from brain cells (So et al., 2005) using the primer forward 5'-CAAGAGCCCATTT TCCAC-3' and reverse 5'-AGGCTGCAGTC GACAGCT-3'.

Table.1 Primers selected for amplification of GnRH II, GnRH III, LHb and FSHbcDNA

\begin{tabular}{|c|c|c|c|c|}
\hline S.NO & GENE & PRIMEI & & REFERENCE \\
\hline \multirow[t]{2}{*}{1} & \multirow[t]{2}{*}{ GnRH II } & Forward & ATGGTGCTGGTCTGCAGGCTG & \multirow[t]{2}{*}{ Kuo et al.,, 2005} \\
\hline & & Reverse & GTAGGAACTGCTGCAAATGGGT & \\
\hline \multirow[t]{2}{*}{2} & \multirow[t]{2}{*}{ GnRH III } & Forward & CACAGCAGTTTTAGCATGGAGTG & \multirow[t]{2}{*}{ Kuo et al., 2005} \\
\hline & & Reverse & ACACTCTTCCCCGTCTGTCGG & \\
\hline \multirow[t]{2}{*}{3} & \multirow[t]{2}{*}{$\mathrm{LHb}$} & Forward & CAAGAGCCCATTTTCCAC & \multirow[t]{2}{*}{ So et al.,, 2005} \\
\hline & & Reverse & AGGCTGCAGTCGACAGCT & \\
\hline \multirow[t]{2}{*}{4} & \multirow[t]{2}{*}{ FSHb } & Forward & CAGCTGTCGGCTCACCAATA & \multirow{2}{*}{$\begin{array}{l}\text { NCBI/Primer- } \\
\text { BLAST(AB003583.1) }\end{array}$} \\
\hline & & Reverse & GCAAAGCAGTGTTTGGTTTCC & \\
\hline
\end{tabular}

Table.2 PCR protocol used for amplifying GnRH II, GnRH III, LHb and FSHbcDNA

\begin{tabular}{|l|l|l|l|l|}
\hline Step & Process & Temperature & \multicolumn{2}{|l|}{ Duration } \\
\hline $\mathbf{1}$ & Initial denaturation & $94^{\circ} \mathrm{C}$ & $10 \mathrm{~min}$ & \\
\hline $\mathbf{2}$ & Denaturation & $94^{\circ} \mathrm{C}$ & $30 \mathrm{sec}$ & 35 \\
\hline $\mathbf{3}$ & Annealing & $52^{\circ} \mathrm{C}(\mathrm{GnRH}$ II and GnRH III $)$ & $40 \mathrm{sec}$ & cycles \\
& & $53^{\circ} \mathrm{C}(\mathrm{LHb})$ & & \\
\cline { 3 - 4 } & & $51^{\circ} \mathrm{C}(\mathrm{FSHb})$ & & \\
\hline $\mathbf{4}$ & Extension & $72^{\circ} \mathrm{C}$ & $1 \mathrm{~min}$ & \\
\hline $\mathbf{5}$ & Final extension & $72^{\circ} \mathrm{C}$ & $10 \mathrm{~min}$ & \\
\hline
\end{tabular}


Fig.1 RNA isolated from L.thermalis; Lane 1: 100bp ladder; Lane 7- 8: Total RNA; Lane 6-5: Negative control

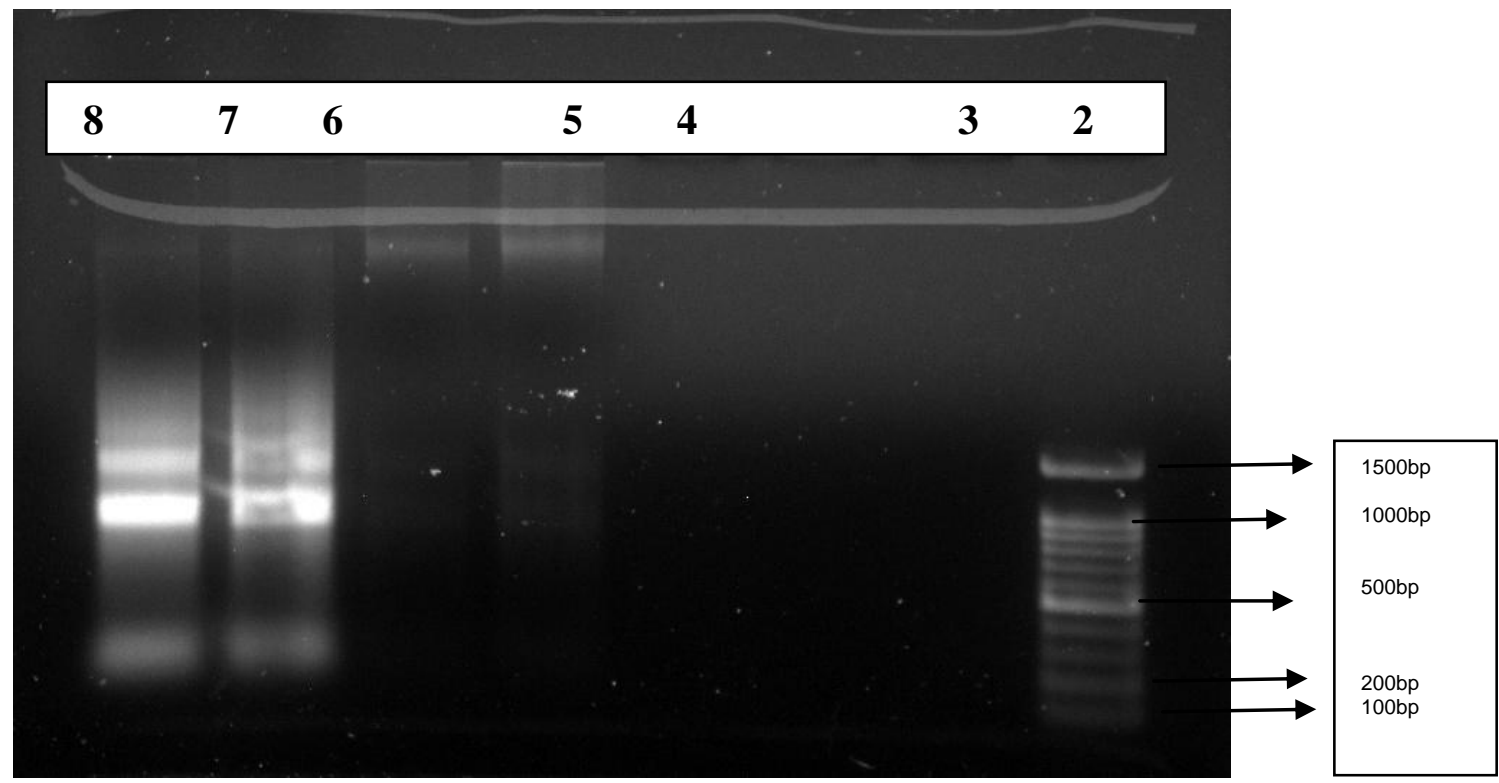

Fig.2 PCR amplified genes (FSHb, GnRH II, GnRH III) of L. thermalis; Lane 1: 100bp ladder ; Lane 3: GnRH II; Lane 5: GnRH III; Lane 6: LHb

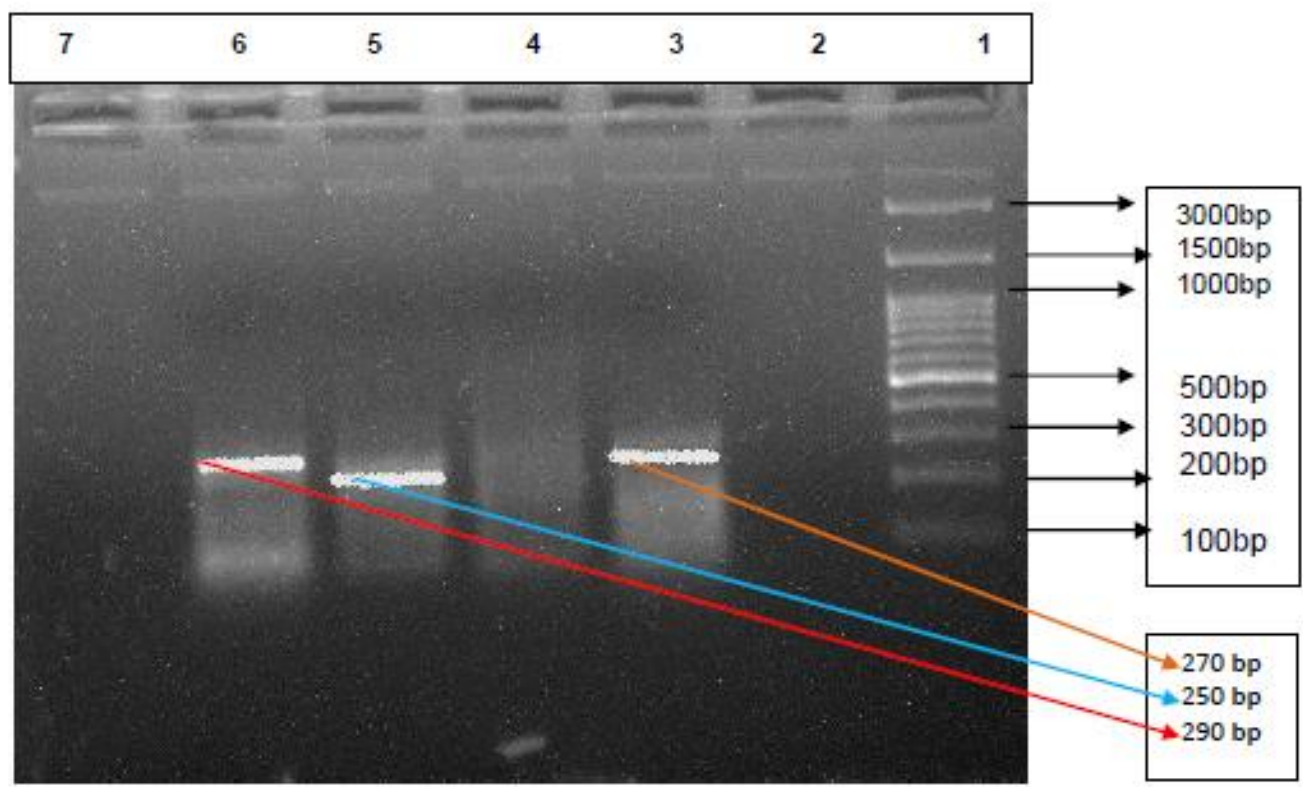


Fig.3 PCR amplified genes (FSHb) of L. thermalis; Lane 1: 100bp ladder; Lane 3-4: FSHb

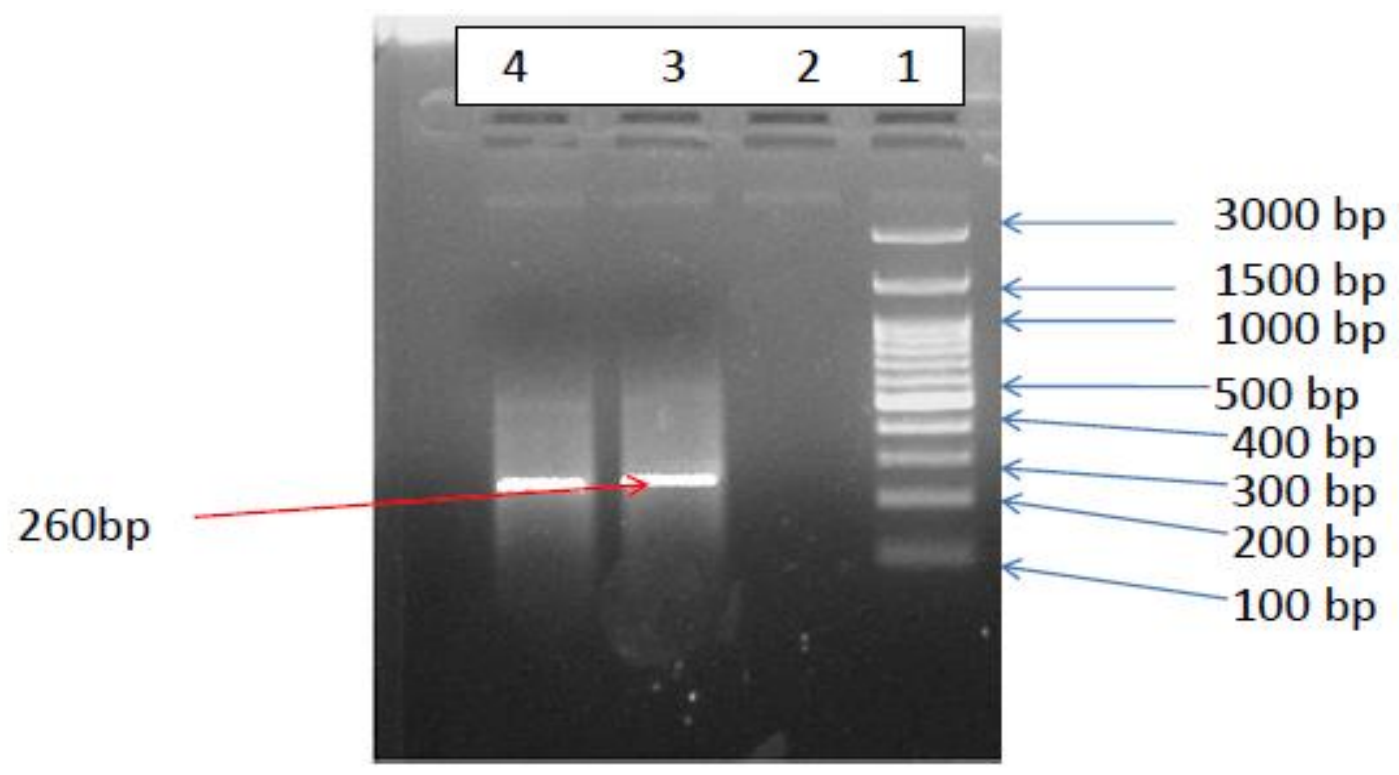

The PCR product size of FSHb gene examined in this study was 260 bp from ovarian cells of Lepidocephalus thermalis using the primers, forward 5'CAGCTGTCGGCTCACCAATA-3' and reverse 5'-GCAAAGCAGTGTTTGGT TTCC-3'. In zebra fish, So et al., (2005) recorded $1038 \mathrm{bp}$ size of FSH from brain cells using primers forward 5'-CATTGATTCCCA GATGAGGA-3' and reverse 5'-TTGCATGA CATACTCAGCAGCT-3'. This implies that the expression of $\mathrm{GnRH}, \mathrm{FSHb}$ and $\mathrm{LHb}$ genes are not confined to brain and pituitary, but also express in the ovarian tissues. The identification of GnRH, FSHb and LHb genes synthesied in gonads gives a relatively new direction about their function. The first evidence for expression of $\mathrm{GnRH}$ in gonads was in rat ovary (Oikawa et al., 1990). The first report of GnRH gene expression in the gonads (ovary and testis) of adult midshipman (Porichthysnotatus) was elucidated by Northern blotting (Grober et al., 1995). A number of the GnRH forms are found in fish gonads of several fishes. For instance sGnRH, cGnRHII and sbGnRH, are reported in testis of the cichlid, Haplochromis burtoni (White and Fernald, 1998) by PCR; sGnRH (mRNA1 and mRNA-2) and cGnRH-II are found in ovary and testis of rainbow trout by sequencing (Gray et al., 2002);s GnRH (mRNA-2) was detected in ovary and testis of sockeye salmon by sequencing; GnRH-I was found in adult sea lamprey testis but not in the ovary as examined by Northern blotting (Suzuki et al., 2002). Sherwood and Adams (2005) stated that GnRH was best known in vertebrates for its expression in neurons and play a role in stimulating the release of gonadotropins from the pituitary. However, expression of $\mathrm{GnRH}, \mathrm{FSHb}$ and $\mathrm{LHb}$ along with their receptors was not confined to the brain and pituitary but is widespread in peripheral tissues. Two sites of interest were the ovary and testis because they express both the genes (GnRH,FSHb and LHb) and their receptors. Therefore the result of the present study was in agreement with earlier studies.

In conclusion, the results from present study will serve as a primary data for further research and development in the reproductive genomic aspects of Indian spiny loach (Lepidocephalus thermalis). It provides the 
idea about maintenance of Indian spiny loach (Lepidocephalus thermalis) and the way of preparing the samples for maturation that helps in further analysis in the aspect of reproductive genomic study. The PCR products can be further analyzed and sequenced to get better knowledge about the gonadotropin-releasing hormone II (GnRH II), gonadotropin-releasing hormone III (GnRH III), luteinizing hormone (LH), follicle-stimulating hormone (FSH).

\section{References}

Amano, M., Okubo, K., Ikuta, K., Kitamura, S., Okuzawa, K., Yamada, H., Aida, K. and Yamamori, K., 2002. Ontogenic origin of salmon GnRH neurons in the ventral telencephalon and the preoptic area in masu salmon. General and comparative endocrinology, 127(3), pp.256-262.

Ayyappan, S., Gopalakrishnan, A. and Ganesh Kumar, B., 2010.Species diversification in aquaculture and domestic fish marketing in India. MPEDA Souvenir 2009, pp.13-22.

Carolsfeld, J., Powell, J.F., Park, M., Fischer, W.H., Craig, A.G., Chang, J.P., Rivier, J.E. and Sherwood, N.M., 2000. Primary structure and function of three gonadotropin-releasing hormones, including a novel form, from an ancient teleost, herring. Endocrinology, 141(2), pp.505-512.

Collins, P.M., O’Neill, D.F., Barron, B.R., Moore, R.K. and Sherwood, N.M., (2001).Gonadotropin-releasing hormone content in the brain and pituitary of male and female grass rockfish (Sebastesrastrelliger) in relation to seasonal changes in reproductive status. Biology of reproduction, 65(1), pp.173-179.

Froese, R., Pauly, D., 2009. Fish Base. World Wide Web electronic publication. http://www.fishbase.org, version (02 / 2009).

Gharaei, A., Rahdari, A. and Ghaffari, M., 2011.Induced spawning of Schizothoraxzarudnyi (Cyprinidae) by using synthetic hormones (Ovaprim and HCG). World Journal of Fish and Marine Sciences, 3(6), pp.518-522.

Gray, S.L., Adams, B.A., Warby, C.M., von Schalburg, K.R. and Sherwood, N.M., 2002. Transcription and translation of the salmon gonadotropin-releasing hormone genes in brain and gonads of sexually maturing rainbow trout (Oncorhynchus mykiss). Biology of reproduction,67(5), pp.1621-1627.

Grober, M.S., Myers, T.R., Marchaterre, M.A., Bass, A.H. and Myers, D.A., 1995. Structure, localization, and molecular phylogeny of a GnRHcDNA from a paracanthopterygian fish, the plainfin midshipman (Porichthys notatus). General and comparative endocrinology,99(1), pp.85-99.

Guzmán, J.M., Luckenbach, J.A., Yamamoto, Y. and Swanson, P., 2014. Expression profiles of Fsh-regulated ovarian genes during oogenesis in coho salmon. PloS one, 9(12), p.e114176.

Kah, O., Breton, B., Dulka, J.G., NunezRodriguez, J., Peter, R.E., Corrigan, A., Rivier, J.E. and Vale, W.W., 1986.A reinvestigation of the Gn-RH (gonadotrophin-releasing hormone) systems in the goldfish brain using antibodies to salmon Gn-RH. Cell and tissue research, 244(2), pp.327-337.

Kah, O., Lethimonier, C., Somoza, G., Guilgur, L.G., Vaillant, C. and Lareyre, J.J., 2007. $\mathrm{GnRH}$ and GnRH receptors in metazoa: a historical, comparative, and evolutive perspective. General and comparative endocrinology, 153(1-3), pp.346-364.

Levavi-Sivan, B., Bogerd, J., Mañanós, E.L., Gómez, A. and Lareyre, J.J., 2010.Perspectives on fish gonadotropins and their receptors. General and comparative endocrinology, 165(3), pp.412-437.

Lubzens, E., Young, G., Bobe, J. and Cerdà, J., 2010. Oogenesis in teleosts: how fish eggs are formed. General and comparative endocrinology, 165(3), pp.367-389.

Nagahama, Y. and Yamashita, M., 
2008. Regulation of oocyte maturation in fish. Development, Growth \& Differentiation, 50, pp.S195-S219.

Patiño, R. and Sullivan, C.V., 2002. Ovarian follicle growth, maturation, and ovulation in teleost fish. Fish Physiology and Biochemistry, 26(1), pp.57-70.

Pierce, J.G. and Parsons, T.F., (1981). Glycoprotein hormones. Structure and function. Ann. Rev. Biochem. 50, 465495.

Pierce, J.G., 1988. Gonadotropins: chemistry and biosynthesis. The physiology of reproduction, 1, pp.1335-1348.

Prayogo, N.A., Wijayanti, G.E., Murwantoko Kawaichi, M. and Astuti, P., 2011.Structure and phylogenetic of GnRH genes of Hard-lipped barb (Osteochilushasselti CV). Middle-East Journal of Scientific Research,10(3), pp.332-341.

Rather, M.A., Bhat, I.A. and Sharma, R., 2015. Identification and characterization of chickenII-GnRH (cII-GnRH) gene of Catlacatla (Hamilton, 1822). Eur J ExperBiol, 5(2), pp.53-56.

Rather, M.A., Bhat, I.A. and Sharma, R., 2016. Identification, cDNA cloning, and characterization of luteinizing hormone beta subunit (lhb) gene in Catlacatla. Animal biotechnology, 27(3), pp.148-156.

Sherwood, N.M. and Adams, B.A., 2005. Gonadotropin-releasing hormone in fish: evolution, expression and regulation of the $\mathrm{GnRH}$ gene. Hormones and their receptors in fish reproduction, 4, pp.1-39.

So, W.K., Kwok, H.F. and Ge, W., 2005.Zebrafish gonadotropins and their receptors: II. Cloning and characterization of zebrafish follicle-stimulating hormone and luteinizing hormone subunits-their spatial-temporal expression patterns and receptor specificity. Biology of reproduction, 72(6), pp.1382-1396.

Suzuki, K., Gamble, R.L. and Sower, S.A., 2000. Multiple transcripts encoding lamprey gonadotropin-releasing hormone-I precursors. Journal of Molecular Endocrinology, 24(3), pp.365-376.

White, R.B. and Fernald, R.D., 1998. Genomic structure and expression sites of three gonadotropin-releasing hormone genes in one species. General and comparative endocrinology, 112(1), pp.17-25.

Xiong, F. and Hew, C.L., 1991. Chinook salmon (Oncorhynchus tschawytscha) gonadotropin II $\beta$ subunit gene encodes multiple messenger ribonucleic acids. Canadian journal of zoology, 69(10), pp.2572-2578.

Yaron, Z., 1995. Endocrine control of gametogenesis and spawning induction in the carp. Aquaculture, 129(1-4), pp.49-73.

Yaron, Z., Gur, G., Melamed, P., Rosenfeld, H., Elizur, A., Levavi-Sivan, B. 2003.Regulation of fish gonadotropins. Int. Rev. Cytol. 225, 131-185.

Yoshiura, Y., Suetake, H., Aida, K., 1999. Duality of gonadotropin in a primitive teleost, Japanese eel (Anguilla japonica). Gen. Comp. Endocrinol. 114, 121-131.

Zohar, Y. and Mylonas, C.C., 2001. Endocrine manipulations of spawning in cultured fish: from hormones to genes. In Reproductive Biotechnology in Finfish Aquaculture. pp. 99-136.

\section{How to cite this article:}

Hamsavalli, R., J. Jaculine Pereira, K. Karal Marx and Jeya Shakila, R. 2019. Analysis of Gonadotropin Releasing Hormone (GnRH), Leutinizing Hormone (LHb) and Follicle Stimulating Hormone (FSHb) Genes in Indian Spiny Loach (Lepidocephalus thermalis). Int.J.Curr.Microbiol.App.Sci. 8(04): 1004-1011. doi: https://doi.org/10.20546/ijcmas.2019.804.116 